\title{
Composição Químico-Bromatológica da Casca de Café Tratada com Amônia Anidra e Sulfeto de Sódio
}

\section{Alexandre Lima de Souza ${ }^{2}$, Rasmo Garcia ${ }^{3}$, Odilon Gomes Pereira ${ }^{3}$, Paulo Roberto Cecon ${ }^{4}$, Sebastião de Campos Valadares Filho ${ }^{3}$, Mario Fonseca Paulino ${ }^{3}$}

\begin{abstract}
RESUMO - Um experimento foi conduzido para avaliar os efeitos de diferentes combinações de amônia anidra $(0,0 ; 2,2 ; 3,2 ;$ e $4,2 \%$ na matéria seca) e sulfeto de sódio $(0,0 ; 2,1 ; 3,1 ;$ e $4,1 \%)$ sobre a composição químico-bromatológica e a digestibilidade in vitro da matéria seca da casca de café (DIVMS). O teor de proteína bruta aumentou em função dos níveis crescentes de amônia anidra. A retenção de nitrogênio diminuiu com os aumentos dos níveis de amônia e de sulfeto. Os teores de nitrogênio insolúvel em detergente neutro e nitrogênio insolúvel em detergente ácido em relação ao nitrogênio total foram sensivelmente reduzidos em função dos níveis crescentes de amônia, sendo, porém, pouco alterados pela adição de sulfeto. Apesar de a aplicação de amônia anidra e sulfeto de sódio nas diferentes combinações utilizadas ter elevado a quantidade de nitrogênio disponível e reduzido os teores de hemicelulose, estas mudanças não foram suficientes para aumentar a DIVMS da casca de café.
\end{abstract}

Palavras-chave: amonização, digestibilidade in vitro, resíduo agroindustrial

\section{Chemical-Bromatologic Composition of Coffee Peel Treated with Anhydrous Ammonia and Sodium Sulphide}

\begin{abstract}
An experiment was conducted to evaluate the effects of different combination of levels of ammonia (0.0, 2.2, $3.2,4.2 \%$ by weight of dry matter) and sodium sulphide $(0.0,2.1,3.1,4.1 \%)$ on chemical-bromatologic composition and "in vitro" dry matter digestibility (IVDMD) of coffee peel with $30 \%$ of moisture. The crude protein (CP) content increased due to the crescent levels of anhydrous ammonia. The nitrogen retention (NR) decreased as the ammonia and sulphide levels increased. The contents of insoluble nitrogen in neutral and acid detergent related to the total nitrogen were reduced as levels of ammonia increased; however they were little altered by the addition of sodium sulphide. Although the application of anhydrous ammonia and sodium sulphide when combined have increased soluble nitrogen and reduced the hemicellusose contents, the changes were not sufficient to increase the IVDMD of coffee peel.
\end{abstract}

Key Words: amonniation, in vitro digestibility, agroindustrial residue

\section{Introdução}

A baixa produção de forragens no Brasil-Central, durante o período de abril a setembro, tem sido responsável, entre outros fatores, pela reduzida produtividade dos bovinos. Visando amenizar os problemas causados pela escassez de forragens de boa qualidade nesse período, diversas opções têm sido propostas, dentre elas o aproveitamento de resíduos da agroindústria.

A casca de café, resíduo proveniente do beneficiamento do grão, pode representar grande potencial de utilização na alimentação dos ruminantes. Segundo dados do ANUÁRIO ESTATÍSTICO DO BRASIL (1998), o Brasil produz 3.338.073 t de café em coco, resultando após cada safra em mais de 1.650.000 t de casca. Todavia, além da baixa disponibilidade de $\mathrm{N}$ e da presença de taninos e cafeína, a casca de café possui elevado teor de fibra, que, por sua vez, apresenta-se bastante lignificada (TEIXEIRA, 1995; BARCELOS et al., 1997). Essas características contribuem para diminuir a palatabilidade e digestibilidade, reduzindo o consumo e o desempenho animal.

Na tentativa de melhorar o valor nutritivo dos volumosos em geral, vários tratamentos químicos têm sido testados (OWEN et al., 1984). Diversos resultados de pesquisa têm evidenciado que a amonização, utilizando amônia anidra ou uréia, pode melhorar, de maneira significativa, o valor nutritivo de gramíneas

1 Parte da tese de M.Sc, apresentada pelo primeiro autor à UFV, Viçosa-MG.

2 Zootecnista, estudante de Doutorado, DZO/UFV. E.mail: alsouza@alunos.ufv.br

3 Professor do Departamento de Zootecnia, UFV. Bolsista do Cnpq.

4 Professor do Departamento de Informática, UFV. 
forrageiras em estádio avançado de maturidade, palhadas e resíduos diversos (PAIVA et al., 1995; ROSA et al., 1998). De modo geral, tais pesquisas enfatizam aumento no teor de compostos nitrogenados, além de alterações na estrutura física da parede celular, principalmente solubilização da hemicelulose. Segundo GOTO e YOKOE (1996), há dois efeitos distintos que, juntos, agem para aumentar a degradabilidade de palhadas tratadas com amônia. Com relação ao primeiro, menciona-se a amônia agindo como um álcali, promovendo pequenas quebras nos interpolímeros que ligam estruturas contendo ligações do tipo éster, resultando em rompimento da estrutura da parede celular e em aumento na sua hidratação. O segundo refere-se à habilidade da amônia em formar complexo com a celulose, reduzindo a sua cristalinidade, através de rompimentos das pontes de hidrogênio, aumentando a sua fragilidade e proporcionando melhor digestão enzimática. Esses fatores, juntos, provocam fragmentação mais rápida do material ingerido e melhoram a eficiência dos microrganismos no ataque às partículas.

$\mathrm{Na}$ busca para melhorar a efetividade da amonização sobre a preservação e o valor nutritivo dos materiais tratados, a aplicação de dióxido de enxofre, sulfeto de sódio e o aumento da umidade do material são procedimentos que têm sido utilizados. $\mathrm{O}$ tratamento de forragens utilizando o $\mathrm{SO}_{2}$ e $\mathrm{Na}_{2} \mathrm{~S}$ visa solubilizar partes da fração fibrosa da forragem ou mesmo potencializar os efeitos da amonização, principalmente no que tange à melhoria da digestibilidade das forragens amonizadas (OWEN et al., 1984; LEAL et al., 1994).

Diante do grande volume de casca de café que anualmente é produzido no Brasil e das poucas informações científicas sobre tratamentos químicos que possam melhorar a qualidade desse resíduo, conduziu-se um experimento, objetivando avaliar os efeitos de doses de amônia anidra e sulfeto de sódio na casca de café, com teor de umidade reconstituído, sobre os teores de matéria seca, proteína bruta, nitrogênio insolúvel em detergente neutro, nitrogênio insolúvel em detergente ácido, retenção de nitrogênio, fibra em detergente neutro, fibra em detergente ácido, hemicelulose, celulose, lignina e digestibilidade in vitro da matéria seca.

\section{Material e Métodos}

Este estudo foi conduzido nas dependências do Departamento de Zootecnia da Universidade Federal de Viçosa (UFV), em Viçosa, MG, no período de
29/05 a 20/08/98.

A casca de café utilizada neste trabalho foi proveniente de indústrias beneficiadoras de café, localizadas no sul do Estado de Minas Gerais. Nessas indústrias, o processamento do café é realizado por via seca, no qual, após a lavagem preliminar e a separação dos frutos em diferentes estádios de maturação, o grão é submetido à secagem. Em seguida, o café em coco, forma como o grão é colhido, é descascado, gerando proporções semelhantes de café beneficiado e casca. Na casca estão contidos a polpa, a mucilagem e o pergaminho, ou casquinha (CAIELLI, 1984; VEGRO e CARVALHO, 1994). Na Tabela 1 é apresentada a composição químico-bromatológica da casca de café utilizada no experimento.

Este experimento foi conduzido de acordo com o

Tabela 1 - Composição químico-bromatológica e digestibilidade in vitro da casca de café

Table 1 - Chemical composition and in vitro digestibility of coffee peel

\begin{tabular}{|c|c|}
\hline $\begin{array}{l}\text { Componentes } \\
\text { Components }\end{array}$ & $\%$ \\
\hline Matéria seca & 83,48 \\
\hline Dry matter & \\
\hline Proteína bruta $^{1}$ & 10,99 \\
\hline Crude protein ${ }^{1}$ & \\
\hline Fibra em detergente neutro ${ }^{1}$ & 50,28 \\
\hline Neutral detergent fiber ${ }^{1}$ & \\
\hline Fibra em detergente ácido ${ }^{1}$ & 35,59 \\
\hline Acid detergent fiber ${ }^{l}$ & \\
\hline Hemicelulose $^{1}$ & 14,69 \\
\hline Hemicellulose $e^{1}$ & \\
\hline Celulose $^{1}$ & 22,72 \\
\hline Cellulose $e^{1}$ & \\
\hline Lignina $^{1}$ & 12,38 \\
\hline Lignin $^{1}$ & \\
\hline Extrato etéreo $^{1}$ & 1,62 \\
\hline Ether extract ${ }^{1}$ & \\
\hline Carboidratos solúveis em álcool $^{1}$ & 17,42 \\
\hline Alcool-soluble carbohydrates ${ }^{1}$ & \\
\hline Amido ${ }^{1}$ & 2,28 \\
\hline Starch $^{1}$ & \\
\hline Nitrogênio insolúvel em detergente neutro ${ }^{2}$ & 33,91 \\
\hline Neutral detergent insoluble nitrogen ${ }^{2}$ & \\
\hline $\begin{array}{l}\text { Nitrogênio insolúvel em detergente ácido } \\
\text { Acid detergent insoluble nitrogen }\end{array}$ & 26,61 \\
\hline Cinza $^{1}$ & 7,44 \\
\hline Ash & \\
\hline $\begin{array}{l}\text { Digestibilidade in vitro da matéria seca }{ }^{1} \\
\text { In vitro dry matter digestibility }\end{array}$ & 59,46 \\
\hline $\begin{array}{l}\text { Digestibilidade in vitro da fibra } \\
\text { em detergente neutro } \\
\text { In vitro neutral detergent } \\
\text { fiberdigestibility }\end{array}$ & 26,65 \\
\hline
\end{tabular}

${ }^{1} \mathrm{Na}$ base da materia seca (As dry matter basis).

${ }^{2} \mathrm{Na}$ base da proteína bruta (As crude protein basis). 
Rev. bras. zootec.

esquema fatorial $4 \times 4$, sendo quatro níveis de amônia anidra $(0 ; 2,2 ; 3,2 ; \mathrm{e} 4,2 \%)$ e quatro níveis de sulfeto de sódio $(0 ; 2,1 ; 3,1 ; \mathrm{e} 4,1 \%)$, dispostos num delineamento inteiramente casualizado, com três repetições.

A casca de café, antes de ser amonizada, foi espalhada sobre uma lona plástica, na qual foi realizada a sua homogeneização. Em seguida, foram colocados 7,5 kg de casca em sacos plásticos, com capacidade para 80 litros, aos quais se adicionou água, visando elevar o teor de umidade de 16 para $30 \%$. Nesse procedimento foram utilizados baldes plásticos com capacidade para 40 litros, efetuando-se a mistura entre a casca e a água, manualmente. $\mathrm{O}$ sulfeto de sódio foi previamente diluído na água utilizada para reconstituir o teor de umidade da casca.

A quantidade de amônia e sulfeto aplicada foi calculada em função da matéria seca (MS) original do subproduto utilizado. Em cada saco plástico usou-se uma mangueira plástica de 3/8", com extremidade inferior obstruída. Visando obter melhor distribuição da amônia no material, foram feitos furos, de $5 \mathrm{~mm}$, na parte da mangueira, que ficou em contato com a casca de café. Aproximadamente $10 \mathrm{~cm}$ dessa mangueira foram projetados para o exterior de cada saco plástico, por onde foi feita a conexão com a mangueira que estava ligada ao botijão de amônia anidra. Em seguida, os sacos foram vedados com fitas plásticas adesivas, após prévia expulsão do ar.

Para aplicação da amônia, utilizou-se um cilindro com capacidade para $28 \mathrm{~kg}$ de amônia anidra. Esse cilindro foi colocado deitado, de modo a facilitar a saída da amônia, sobre uma balança eletrônica com capacidade para $50 \mathrm{~kg}$ e precisão de $5 \mathrm{~g}$. A quantidade de amônia aplicada foi controlada pela diferença de peso registrada na balança.

Oitenta e dois dias após a aplicação da amônia e do sulfeto, foram coletadas amostras referentes a cada unidade experimental, as quais, foram colocadas em sacos plásticos e em seguida, armazenadas em "freezer" para posteriores análises. Com a finalidade de não perder o nitrogênio proveniente da amonização, realizou-se a pré-secagem de todas as amostras por liofilização, procedendo em seguida a moagem das mesmas, em moinho tipo "Willey", utilizando peneira de $1 \mathrm{~mm}$.

Após a moagem, as amostras foram colocadas em vidros, identificadas e armazenadas em local fresco, até o momento de serem submetidas às análises químico-bromatológicas.

As análises de matéria seca (MS), nitrogênio total, fibra em detergente neutro (FDN), fibra em detergente ácido (FDA), hemicelulose, celulose, lignina e digestibilidade in vitro da matéria seca (DIVMS) foram determinados de acordo os procedimentos descritos por SILVA (1990). Para determinação da DIVMS utilizou-se o método de duas etapas (96 horas de incubação). Já os teores de nitrogênio insolúvel em detergente neutro (NIDN) e nitrogênio insolúvel em detergente ácido (NIDA) foram determinados de acordo com os procedimentos descritos por LICITRA et al. (1996), sendo expressos como porcentagem do nitrogênio total NIDN/NT e NIDA/ NT. Os dados percentuais para retenção de nitrogênio $(\mathrm{RN})$ na casca de café amonizada, em relação à não-amonizada, foram obtidos segundo os procedimentos descritos por PAIVA (1992).

Os resultados foram interpretados estatisticamente, utilizando-se a metodologia de superfície de resposta. A escolha do modelo foi feita com base no coeficiente de determinação e na significância dos coeficientes de regressão, utilizando-se o teste " $t$ ", de Student, a $1 \%$ de probabilidade.

As análises estatísticas foram realizadas, utilizando-se o programa SAEG (Sistema de Análises Estatística e Genética), desenvolvido na UFV.

\section{Resultados e Discussão}

Ao submeter os valores de proteína bruta e retenção de nitrogênio à técnica de superfície de resposta, observou-se efeito $(\mathrm{P}<0,01)$ dos níveis de amônia anidra e de sulfeto de sódio em ambas as variáveis.

Os valores médios de PB encontram-se na Tabela 2. Na Figura 1, mostra-se o comportamento dos valores de PB em função dos níveis de amônia $(\mathrm{N})$ e sulfeto (S), estimados pela seguinte equação de regressão: $\hat{Y}=12,7687+4,87664 * * \mathrm{~N}-0,22145 * \mathrm{~N}-0,221145^{* *} \mathrm{~N}^{2}$ $0,486246 * * \mathrm{~S}\left(\mathrm{R}^{2}=0,99\right)$.

Foram observados aumentos nos teores de proteína bruta da casca de café, à medida que se elevaram as doses de amônia anidra.

Os aumentos nos teores de PB em materiais amonizados foram consistentes em vários trabalhos de pesquisa (NEIVA et al., 1998; SANTANA et al., 1997). Esses incrementos ocorreram em função da liberação de compostos nitrogenados provenientes da amônia anidra, amônia líquida ou uréia durante o processo de amonização. Contudo, a magnitude desses aumentos apresentou grande variação, o que pode ser atribuído às diferentes condições de tratamento, como níveis de amônia aplicados, temperatura 
986

Tabela 2 - Teores médios de proteína bruta da casca de café com alta umidade submetida a diferentes níveis de amônia anidra e sulfeto de sódio

Table 2 - Average crude protein contents of coffee peel with high moisture submitted to different levels of anhydrous ammonia and sodium sulphide

\begin{tabular}{|c|c|c|c|c|c|}
\hline \multirow[t]{2}{*}{$\begin{array}{l}\text { Níveis de sulfeto } \\
\text { de sódio } \\
\text { Sodium sulphide } \\
\text { levels }\end{array}$} & \multicolumn{3}{|c|}{$\begin{array}{c}\text { Proteína bruta }{ }^{1} \\
\text { Crude protein }\end{array}$} & & \multirow[t]{2}{*}{$\begin{array}{c}\text { Média } \\
\text { Mean }\end{array}$} \\
\hline & 0,0 & 2,2 & 3,2 & 4,2 & \\
\hline 0,0 & 11,60 & 23,24 & 25,90 & 29,87 & 22,65 \\
\hline 2,1 & 12,05 & 21,49 & 24,48 & 28,46 & 21,62 \\
\hline 3,1 & 11,53 & 21,28 & 24,09 & 28,12 & 21,25 \\
\hline 4,1 & 11,22 & 20,18 & 24,08 & 26,94 & 20,60 \\
\hline Média & 11,60 & 21,54 & 24,64 & 28,35 & 21,53 \\
\hline
\end{tabular}

${ }^{1} \mathrm{Na}$ base da materia seca (As dry matter basis).

ambiente, teor de umidade, período de amonização e qualidade do material, dentre outros. Em condições práticas, as doses de amônia aplicadas, o teor de umidade inicial e a temperatura ambiente foram os fatores mais importantes a influenciar o efeito da amonização em palhadas (SCHNEIDER e FLACHOWSKY, 1990).

Com relação ao uso do sulfeto de sódio, este não

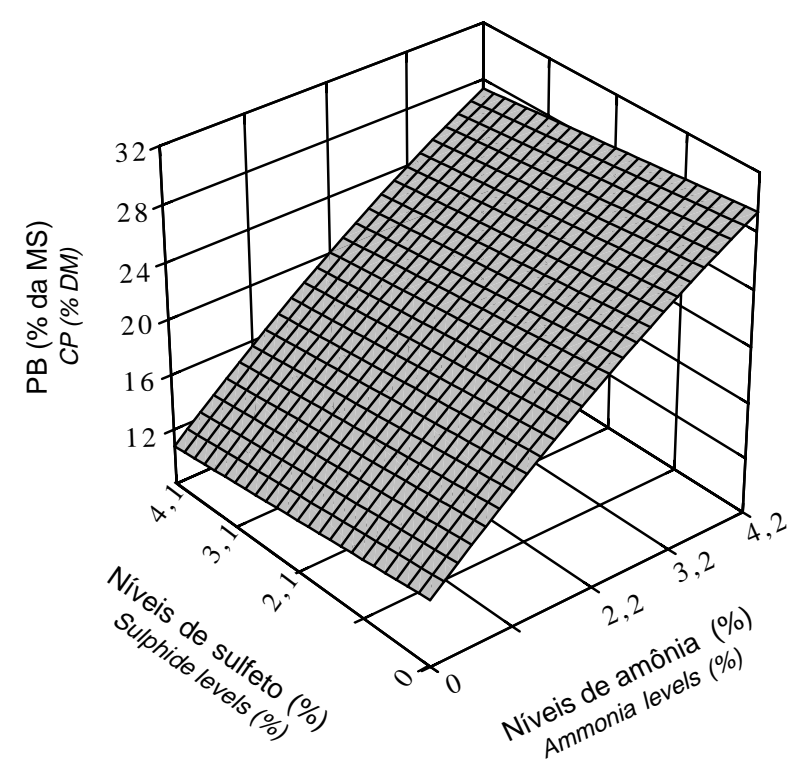

** Significativo a $1 \%$ de probabilidade, pelo teste $\mathrm{t}$.

** Significant at $1 \%$ of probability, by $t$ test.

Figura 1 - Estimativa dos teores de proteína bruta (PB) em função dos níveis de amônia anidra e de sulfeto de sódio na casca de café com alta umidade.

Figure 1 - Estimate of crude protein contents $(C P)$ in function of levels anhydrous ammonia and sodium sulphide of coffee peel with high moisture. promoveu aumentos nos teores de proteína bruta, nem melhorou a retenção do nitrogênio na casca de café amonizada. Os teores médios de PB estimados em função dos níveis de amônia $(0 ; 2,2 ; 3,2 ;$ e $4,2 \%)$ e de sulfeto de sódio foram de 12,$8 ; 22,4 ; 26,1 ; 29,3$; e 10,$7 ; 20,4 ; 24,1 ;$ e $27,6 \%$ da MS, respectivamente nos níveis de 0 e $4,1 \%$ de sulfeto.

Esses resultados contrastam com os encontrados por DRYDEN e LENG (1988), que verificaram melhoria significativa na retenção de nitrogênio quando o $\mathrm{SO}_{2}$ foi aplicado junto com a amônia anidra, aumentando, por conseguinte, o teor de proteína bruta da palhada de cevada.

Os valores da retenção de nitrogênio (RN) em função dos níveis de amônia e sulfeto, estimados pela equação de regressão $\hat{Y}=114,61-6,41 * * \mathrm{~N}-3,32963 * * \mathrm{~S}$ $\left(\mathrm{r}^{2}=0,93\right)$, encontram-se na Figura 2. Observando o comportamento desses dados, verificou-se diminuição na $\mathrm{RN}$ à medida que se elevaram os níveis de amônia anidra e sulfeto de sódio. Os valores médios, estimados em função dos níveis de amônia $(2,2 ; 3,2 ;$ e $4,2 \%)$ e de sulfeto de sódio, foram de 100,$5 ; 94,0 ; 87,7 ; 86,9 ; 80,4 ;$ e $74,0 \%$, respectivamente, nos níveis de 0 e $4,1 \%$ de sulfeto.

Os altos valores de retenção de nitrogênio podem

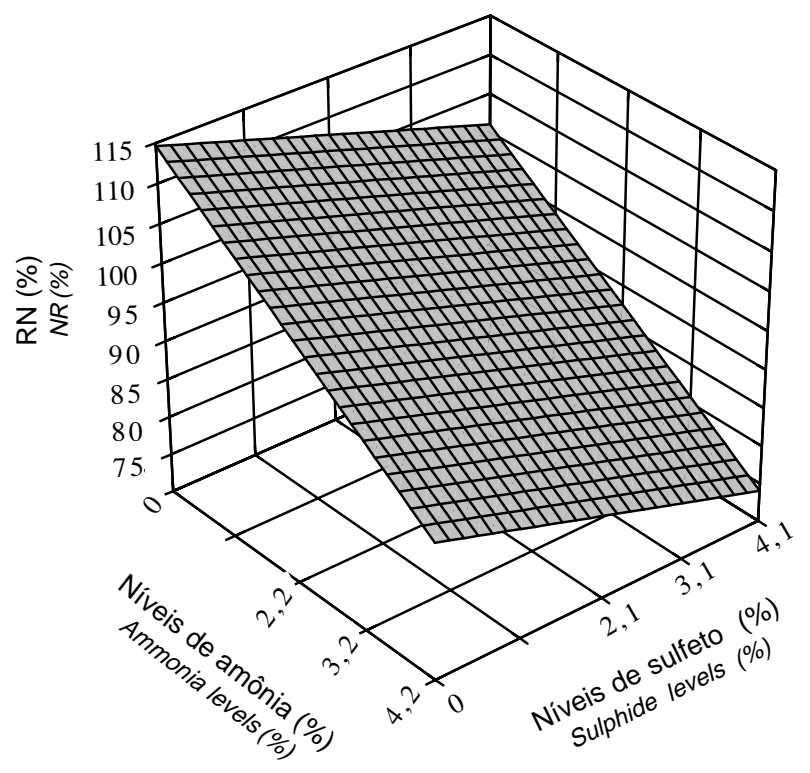

* * Significativo a $1 \%$ de probabilidade, pelo teste $\mathrm{t}$.

Figura 2 - Estimativa dos valores da retenção de nitrogênio (RN) em função dos níveis de amônia anidra e de sulfeto de sódio na casca de café com alta umidade.

Figure 2 - Estimate of nitrogen retention (NR) values in function of levels anhydrous ammonia and sodium sulphide of coffee peel with high moisture. 
Rev. bras. zootec.

ter ocorrido em função do elevado teor de umidade da casca de café utilizada (30\%). Outra explicação para os diferentes valores de $\mathrm{RN}$ encontrados em diferentes materiais refere-se aos pontos de ligação para o nitrogênio (N). Segundo Wylie e Steem (1988), citados por PAIVA (1992), os volumosos em geral apresentam diferentes números de "sítios" de ligação para o N. Todavia, com a elevação das doses de amônia, ocorre, em determinado momento, saturação desses "sítios", não permitindo mais que o nitrogênio adicionado seja retido nessa forragem.

Ao submeter os valores de NIDN e de NIDA em relação ao conteúdo de nitrogênio total à técnica de superfície de resposta, observou-se efeito $(\mathrm{P}<0,01)$ dos níveis de amônia anidra e de sulfeto de sódio, em ambas as variáveis.

O comportamento dos valores das relações NIDN/NT e NIDA/NT estimados pelas equações $\hat{Y}=33,0532$ $6,97151^{* *} \mathrm{~N}+0,69796 * * \mathrm{~N}^{2}+0,376318 * * \mathrm{~S}\left(\mathrm{R}^{2}=0,98\right)$ e $\hat{Y}=25,7641-6,94722 * * \mathrm{~N}+0,812595 * *$ $\mathrm{N}^{2}+0,231762 * * \mathrm{~S}\left(\mathrm{R}^{2}=0,99\right)$, respectiva-mente, pode ser verificado pelos dados da Figura 3. Como pode ser observado nesta figura, valores de NIDN/NT e NIDA/ NT apresentaram decréscimos acentuados com a elevação dos níveis de amônia anidra. Entretanto, ao fixar os níveis de amônia, verificaram-se acréscimos de 0,376318 e 0,231762 unidades percentuais nos teores de NIDN/NT e NIDA/NT, respectivamente, em cada unidade de sulfeto.

O decréscimo nos teores de NIDN/NT e NIDA/ NT encontrados no presente trabalho, decorrentes do processo de amonização, evidenciam que a adição do nitrogênio não-protéico, através da amônia anidra, aumenta a quantidade de nitrogênio disponível para a síntese de proteína microbiana.

Resultados semelhantes foram observados por REIS et al. (1998), que, ao tratarem fenos de capimbraquiária e capim-jaraguá, em estádio de maturação das sementes, com amônia anidra (0 ou 3\% da MS), encontraram valores de 64,4 e 22,5 de NIDN/NT e de 57,9 e $20,5 \%$ de NIDA/NT, respectivamente, com as doses aplicadas.

Os dados referentes aos teores de fibra em detergente neutro (FDN) e de hemicelulose submetidos à técnica de superfície de resposta, apresentaram efeito $(\mathrm{P}<0,01)$ dos níveis de amônia anidra e de sulfeto de sódio em ambas as variáveis.

$\mathrm{Na}$ figura 4 é encontrados o comportamento dos valores da FDN estimados pela equação . Ao avaliar níveis de amônia dentro de cada nível de sulfeto, constatou-se que, nos níveis de $0 ; 2,1 ; 3,1$; e $4,1 \%$ de sulfeto, os teores máximos de FDN foram, respectivamente, de 51,$33 ; 50,72 ; 50,43$; e $50,14 \%$ quando foram aplicados $2,17 \%$ de amônia anidra. Como mostrado na Figura 4 os valores da FDN foram
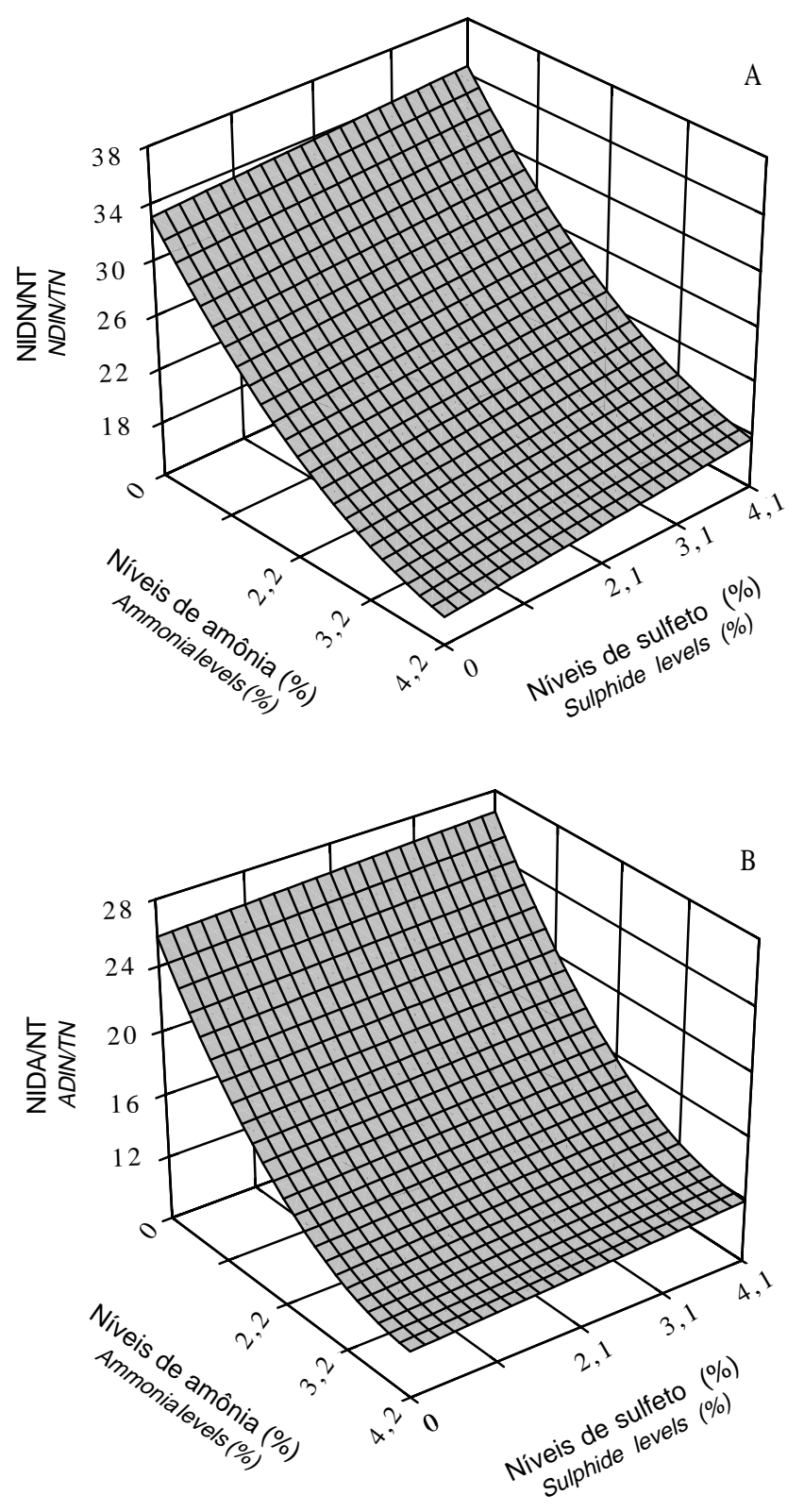

Figura 3 - Estimativa dos valores de nitrogênio insolúvel em detergente neutro, em relação ao nitrogênio total (A), e de nitrogênio insolúvel em detergente ácido, em relação ao nitrogênio total $(B)$, na casca de café com alta umidade submetida a diferentes níveis de amônia anidra e sulfeto de sódio.

Figure 3 - Estimate of neutral detergent insoluble nitrogen values (A) related to the total nitrogen (NDIN/TN) and acid detergent insoluble nitrogen $(B)$ related to the total nitrogen (ADIN/TN), in the coffee peel with high moisture submitted to the different levels of anhydrous ammonia and sodium sulphide. 
poucos alterados pelas diferentes doses de aplicação de amônia e sulfeto aplicados. Tal fato pode ser atribuído, entre outros fatores, a menor quantidade de ligações éster presentes na fração fibrosa das dicotiledôneas (FAHEY, et al. 1993).

O comportamento da variação nos teores de hemicelulose estimados pela equação de regressão $\hat{Y}=15,1139-0,131925 * * \mathrm{~N}-0,289109 * \mathrm{~S}\left(\mathrm{r}^{2}=0,54\right)$ pode ser verificado pela Figura 5 , na qual se observa diminuição no conteúdo de hemicelulose, à medida que aumentam as doses de amônia anidra e de sulfeto de sódio, sendo essas reduções mais pronunciadas com a elevação das doses de sulfeto. De acordo com a equação de regressão, foram observadas reduções de 3,$6 ; 7,8$; e $11,7 \%$ com a aplicação de $4,2 \%$ de amônia + $0,0 \%$ de sulfeto; $4,1 \%$ de sulfeto $+0,0 \%$ de amônia; e $4,2 \%$ de amônia $+4,1 \%$ de sulfeto, respectivamente.

BEN-GHEDALIA e MIRON (1984), em estudos com palha de trigo tratada com $4,0 \%$ de dióxido de enxofre a $70^{\circ} \mathrm{C}$, durante um período de 72 horas, verificaram redução no conteúdo de FDN de 78,5 para

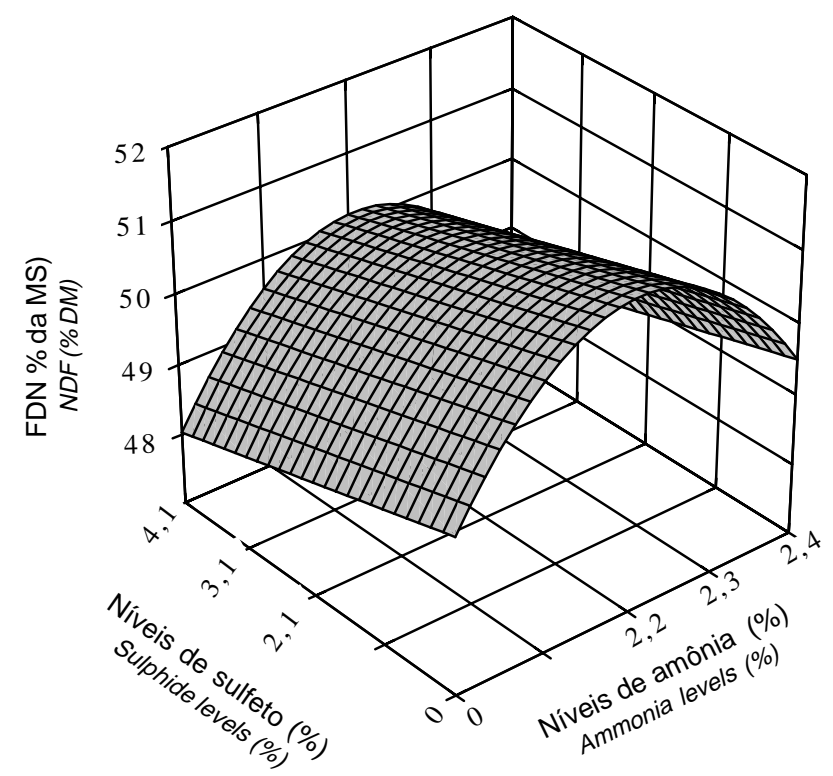

** Significativo a $1 \%$ de probabilidade, pelo teste $\mathrm{t}$.

** Significant at $1 \%$ of probability, by $t$ test.

Figura 4 - Estimativa dos teores de fibra em detergente neutro (FDN) em função dos níveis de amônia anidra e de sulfeto de sódio na casca de café com alta umidade.

Figure 4 - Estimate of neutral detergent fiber (NDF) contents in function of the levels of anhydrous ammonia and sodium sulphide in the coffee peel with high moisture.
$55,5 \%$. Os referidos autores atribuíram essa redução à solubilização parcial da parede celular. Já NASEEVEN e KINCAID (1992), ao utilizarem palha de trigo tratada com amônia anidra ( 0 e 3,5\% da MS) e com várias doses de enxofre ( $0,2,3,4$ e $5 \%$ da MS), verificaram que, apesar de o conteúdo de hemicelulose ter sido reduzido pela amonização, a utilização do dióxido de enxofre nas diferentes doses estudadas foi ineficiente na redução do conteúdo de hemicelulose.

Os teores médios de fibra em detergente ácido (FDA) são apresentados na Tabela 3. Ao submeter esses dados à técnica de superfície de resposta, não se detectou efeito $(\mathrm{P} \geq 0,01)$ dos níveis de amônia anidra e níveis de sulfeto de sódio. Já em relação aos teores de celulose e lignina, detectou-se efeito $(\mathrm{P}<0,01)$ dos níveis de amônia e de sulfeto, em ambas as variáveis.

Os resultados registrados para FDA corroboram aqueles obtidos por NASEEVEN e KINCAID (1992), PAIVA et al. (1995) e ROSA et al. (1998).

O comportamento dos valores de celulose estimados pela equação $\hat{Y}=22,0793+1,16464 * *$

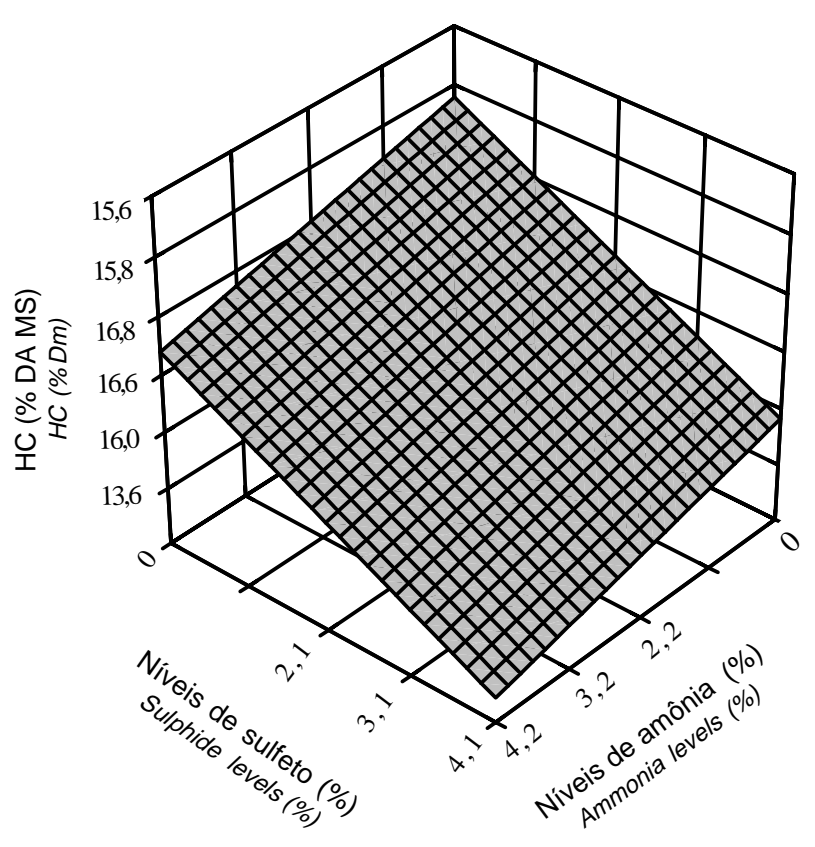

* $*$ Significativo a $1 \%$ de probabilidade, pelo teste t.

** Significant at $1 \%$ of probability, by $t$ test.

Figura 5 - Estimativa dos teores de hemicelulose $(\mathrm{HC})$ em função dos níveis de amônia anidra e de sulfeto de sódio na casca de café com alta umidade.

Figure 5 - Estimate of hemicellulose $(\mathrm{HC})$ contents in function of the levels of anhydrous ammonia and sodium sulphide in the coffee peel with high moisture. 
Rev. bras. zootec.

$\mathrm{N}-0,254566 * * \mathrm{~N}^{2}-0,184615^{* *} \mathrm{~S}\left(\mathrm{R}^{2}=0,77\right)$, é representado, graficamente, na Figura 6. Ao avaliar níveis de amônia dentro de cada nível de sulfeto, constatouse que, nos níveis de $0 ; 2,1 ; 3,1 ;$ e $4,1 \%$ de sulfeto, os teores máximos de celulose foram de 23,41; 23,02; 22,84 ; e $22,65 \%$, respectivamente, quando se aplicaram $2,29 \%$ de amônia anidra.

Tabela 3 - Teores médios da fibra de detergente ácido (FDA) da casca de café com alta umidade submetida a diferentes níveis de amônia anidra e sulfeto de sódio

Table 3 - Average acid detergent fiber (ADF) contents of the coffee peel with high moisture submitted to different levels of anhydrous ammonia and sodium sulphide

\begin{tabular}{|c|c|c|c|c|c|}
\hline \multirow[t]{2}{*}{$\begin{array}{l}\text { Níveis de sulfeto } \\
\text { de sódio } \\
\text { Sodium sulphide } \\
\text { levels }\end{array}$} & \multicolumn{3}{|c|}{$\begin{array}{l}\mathrm{FDA}^{1} \\
A D F^{1}\end{array}$} & $\begin{array}{l}\text { Ira } \\
\text { els }\end{array}$ & \multirow[t]{2}{*}{$\begin{array}{l}\text { Média } \\
\text { Mean }\end{array}$} \\
\hline & 0,0 & 2,2 & 3,2 & 4,2 & \\
\hline 0,0 & 34,6 & 35,86 & 35,99 & 35,19 & 35,44 \\
\hline 2,1 & 34,24 & 35,55 & 36,67 & 35,49 & 35,49 \\
\hline 3,1 & 33,88 & 35,93 & 36,71 & 34,49 & 35,25 \\
\hline 4,1 & 34,60 & 36,17 & 36,84 & 34,50 & 35,53 \\
\hline Média & 34,30 & 35,88 & 36,55 & 34,98 & 35,43 \\
\hline
\end{tabular}

${ }^{1} \mathrm{Na}$ base da matéria seca (As dry matter basis).

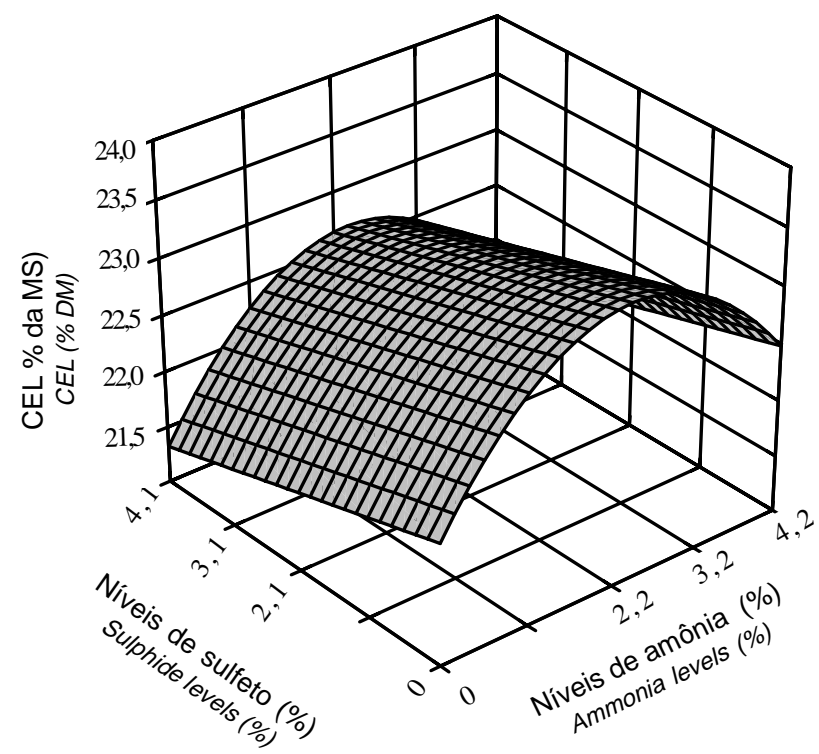

Figura 6 - Estimativa dos teores de celulose (CEL) em função dos níveis de amônia anidra e de sulfeto de sódio na casca de café com alta umidade.

Figure 6 - Estimate of cellulose contents (CEL) in function of levels anhydrous ammonia and sodium sulphide in the coffee peel with high moisture.
Já em relação aos teores de lignina, estimados pela equação $\hat{Y}=11,5146+0,449239 * * \mathrm{~N}-0,0699731 * *$ $\mathrm{N}^{2}+0,188334 * \mathrm{~S}\left(\mathrm{R}^{2}=0,50\right)$, verificou-se que estes aumentaram em função dos níveis crescentes de amônia anidra e de sulfeto de sódio, (Tabela 4). DRYDEN e LENG (1988), em estudos com palha de cevada tratada com 9,5\% de amônia anidra + dióxido de enxofre, verificaram redução no conteúdo de celulose de 41,9 para 35,3\%. Eles verificaram, também, aumento no conteúdo de lignina tratada com amônia ou $\mathrm{SO}_{2}$.

Além do pequeno número de pesquisas realizadas com sulfeto de sódio e dióxido de enxofre, os resultados obtidos com a utilização desses produtos sobre os constituintes da parede celular dos volumosos, em geral, têm sido contraditórios.

Na Tabela 5 são apresentados os valores médios da DIVMS da casca de café com alta umidade, em função dos diferentes níveis de amônia anidra e sulfeto de sódio. Ao submeter esses dados à técnica de superfície de resposta, não se detectou efeito ( $\mathrm{P}>0,01)$ dos níveis de amônia e de sulfeto. Isso pode ser explicado, em parte, pelo fato da casca de café ter apresentado bom valor de DIVMS inicial $(60,6 \%)$. Também FAHEY et al. (1993) relataram que as dicotiledôneas, por apresentarem menor concentração de ácidos hidroxinâmicos esterificados, principalmente ácido p-cumárico e ácido ferúlico, são menos responsivas ao tratamento com agentes alcalinos, quando comparadas às monocotiledôneas.

Resultados diferentes ao deste trabalho foram encontrados por FAHMY e KLOPFENSTEIN (1994) e NASEEVEN e KINCAID (1992), que verificaram aumento na digestibilidade do material tratado, em relação ao testemunha, em estudos utilizando nitrogênio não-protéico (NNP), associado ou não ao $\mathrm{SO}_{2}$. Os aumentos na digestibilidade observados por esses autores foram atribuídos a uma solubilização parcial dos constituintes da parede celular, principalmente lignina, em decorrência da aplicação de $\mathrm{SO}_{2}$ e NNP. A diminuição no conteúdo de lignina permitiria melhor colonização da palhada pelos microrganismos ruminais e melhor ataque destes a ela, segundo os referidos autores.

LEAL et al. (1994), em estudos com palha de sorgo tratada com hidróxido de amônia e dióxido de enxofre, relataram que, apesar de o SO2 ter promovido solubilização de parte do complexo lignocelulósico, essas mudanças não foram suficientes para melhorar a DIVMS. De acordo com esses autores, em adição à solubilização dos polissacarídios da parede celular, o $\mathrm{SO}_{2}$ também pode ter liberado alguns oligossacarídios fenólicos, que podem ter inibido a digestibilidade da fração solúvel da parede celular. 
Tabela 4 - Teores médios de lignina da casca de café com alta umidade submetida a diferentes níveis de amônia anidra e sulfeto de sódio

Table 4 - Lignin contents of the coffee peel with high moisture submitted to different levels of anhydrous ammonia and sodium sulphide

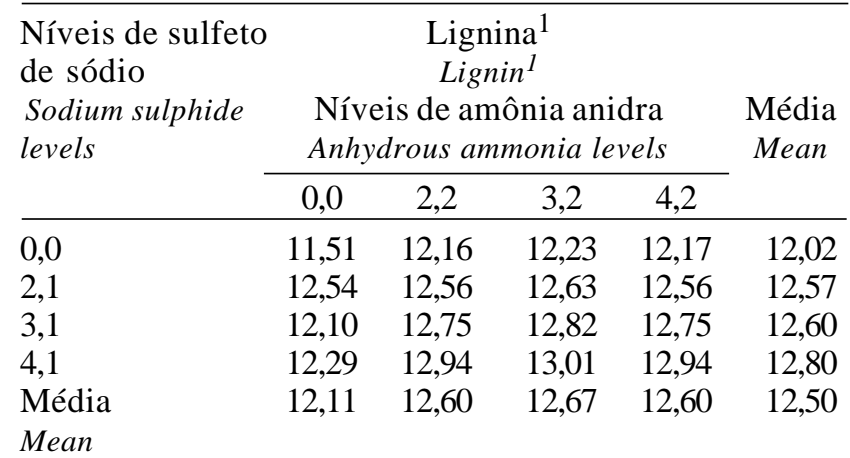

${ }^{1} \mathrm{Na}$ base da matéria seca (As dry matter basis).

Tabela 5 - Valores médios da digestibilidade in vitro da matéria seca (DIVMS) da casca de café com alta umidade e submetida a diferentes níveis de amônia anidra e sulfeto de sódio

Table 5 - Average values of in vitro digestibility of dry matter of coffee peel with high moisture submitted to different levels of anhydrous ammonia and sodium sulphide

\begin{tabular}{|c|c|c|c|c|c|}
\hline $\begin{array}{l}\text { Níveis de sulfeto } \\
\text { de sódio } \\
\text { Sodium sulphide } \\
\text { levels }\end{array}$ & $\begin{array}{l}\text { Nív } \\
\text { Anh }\end{array}$ & $\begin{array}{r}\text { DIV } \\
I V D \\
\text { is de ar } \\
\text { lrous al }\end{array}$ & $\begin{array}{l}\text { IS } \\
D \\
\text { nia ani } \\
\text { tonia le }\end{array}$ & & $\begin{array}{c}\text { Média } \\
\text { Mean }\end{array}$ \\
\hline & 0,0 & 2,2 & 3,2 & 4,2 & \\
\hline 0,0 & 60,66 & 60,44 & 59,30 & 60,10 & 60,12 \\
\hline 2,1 & 62,07 & 59,91 & 60,71 & 62,03 & 61,18 \\
\hline 3,1 & 60,77 & 58,80 & 60,15 & 61,16 & 60,22 \\
\hline 4,1 & 61,30 & 60,86 & 59,58 & 61,60 & 60,80 \\
\hline $\begin{array}{l}\text { Média } \\
\text { Mean }\end{array}$ & 61,20 & 60,00 & 59,94 & 61,22 & 60,59 \\
\hline
\end{tabular}

\section{Conclusões}

A amonização proporcionou efeitos benéficos sobre o conteúdo de nitrogênio da casca de café, diminuindo a relação NIDN/NT e NIDA/NT, promovendo ainda alterações na fração fibrosa deste resíduo, sem, contudo, afetar sua DIVMS.

\section{Referências Bibliográficas}

ANUÁRIO ESTATÍSTICO DO BRASIL. Rio de Janeiro: IBGE, v. 58,1998 . p.3-27.

BARCELOS, A.F., ANDRADE, I.F., VON TIESENHAUSEN, I.M.E.V. et al. 1997. Aproveitamento da casca de café na alimentação de novilhos confinados - resultados do segundo ano. R. Bras. Zootec., 26(6):1215-1221.

BEN-GHEDALIA, D., MIRON, J. 1984. The digestibility of wheat straw treated with sulphur dioxide. J. Agric. Sci., 102 (3):517-520.

CAIELLI. E.L. 1984. Uso da palha de café na alimentação de ruminantes. Inf. Agropec., 10(119):36-38.

DRYDEN, G.M., LENG, R.A. 1988. Effects of ammonia and sulphur dioxide gases on the composition and digestion of barley straw. Anim. Feed Sci. Technol., 19(1/2):121-133.

FAHEY, G.C., BOURQUIN, L. D., TITGEMEYER, E. C. et al. 1993. Postharvest treatment of fibrous feedstuffs to improve their nutritive value. In: JUNG, H.G., BUXTON, R.D., HATFIELD, R.D. et al. (Eds.) Forage cell wall structure and digestibility. Madison: Wisconsin. p.715-766.

FAHMY, S.T.M., KLOPFENSTEIN, T.J. 1984. Treatment with different chemicals and their effects on the digestibility of maize stalks. 2. Intake and in vivo digestibility as affected by chemical treatment and monensin suplementation. Anim. Feed Sci. Technol., 45(3/4):316-323.

GOTO, M., YOKOE, Y. 1996. Ammoniation of barley straw. Effect on celulose crystallinity and water - holding capacity. Anim. Feed Sci. Technol., 58(3/4):239-247.

LEAL, M., SHIMADA, A., HERNÁNDEZ, E. 1994. The effect of nh3 and/or so2 on the compositional and histological characteristics of sorghum stover. Anim. Feed Sci. Technol., 47(1/2):141-150.

LICITRA, G., HERNANDEZ, T.M., VAN SOEST, P.J. 1996. Standardization of procedures for nitrogen fractionation of ruminant feeds. Anim. Feed. Sci. Technol., 57(4):347-358.

NASEEVEN, M.R., KINCAID, R.L. 1992. Ammonia and sulphur dioxide treated straw as a feedstuff for cattle. Anim. Feed Sci. Technol., 37(1/2):111-128.

NEIVA, J.N.M., GARCIA, R., VALADARES FILHO, S.C. et al. 1998. Características químicas da silagem e do rolão de milho amonizados. R. Bras. Zootec., 27(3):461-465.

OWEN, E., KLOPFENSTEIN, T., URIO, N.A. 1994. Treatment with other chemicals. In: SUNDSTOL, F., OWEN, E. (Eds.) Straw and other fibrois by-products as feed. Amsterdam: Elsevier Press. p.248-275.

PAIVA, J.A.J. Níveis de amônia anidra, períodos de amonização e de aeração sobre a composição quimíco - bromatológica e a degradabilidade in situ da palhada de milho (Zea mays L.). Viçosa, MG: UFV, 1992. 162p. Tese (Doutorado em Zootecnia) - Universidade Federal de Viçosa, 1992.

PAIVA, J.A.J., GARCIA, R., QUEIROZ, A.C. et al. 1995. Efeitos dos níveis de amônia anidra e períodos de amonização sobre os teores dos constituintes da parede celular na palhada de milho (Zea mays L.). R. Soc. Bras. Zootec., 24(5):683-692.

REIS, R.A., RODRIGUES, L.R.A., PEREIRA, J.R.A. et al. Procedimentos analíticos para predizer a eficiência da amonização. In: REUNIÃO ANUAL DA SOCIEDADE BRASILEIRA DEZOOTECNIA, 35, 1998, Botucatu. Anais... Botucatu, 1998. p.137-139. 
Rev. bras. zootec.

ROSA, B., REIS, R.A., RESENDE, K.T. et al. 1998. Valor nutritivo do feno de Brachiaria decumbens stapf cv. basilisk submetido a tratamento com amônia anidra ou uréia. R. Bras. Zootec., 27(4):815-822.

SANTANA, A.A.C., GRAÇA, D.S., SALIBA, E.S. et al. Efeito do tempo pós - amonização sobre parâmetros bromatológicos do bagaço de cana-de-açúcar (Saccharum officinarum, L.) oriundo de destilaria de aguardente. In: REUNIÃO ANUAL DA SOCIEDADE BRASILEIRA DE ZOOTECNIA, 34, 1997, Juiz de Fora. Anais... Juiz de Fora: SBZ, 1997. p.438-440.

SCHNEIDER, M., FLACHOWSKY, G. 1990. Studies on ammonia treatement of wheat straw: effects or level of ammonia, moisture content, treatament time and temperature on straw composition and degradation in the rumen of sheep. Anim. Feed Sci. Technol., 29(3/4):252-264.

SILVA, D.J. 1990. Análise de alimentos: métodos químicos e biológicos. Viçosa, MG: UFV. 165p.
TEIXEIRA, J.L. Utilização de resíduos culturais e de Beneficiamento na utilização de bovinos. In: SIMPÓSIO SOBRE NUTRIÇÃO DE BOVINOS, 6, 1995, Piracicaba, Anais... Piracicaba: FEALQ, 1995. p.123-152.

UNIVERSIDADE FEDERAL DE VIÇOSA - UFV. 1997. SAEG - Sistema de análises estatísticas e genéticas. Versão 7.1. Viçosa, MG. 150p. (Manual do usuário).

VEGRO, C.L.R., CARVALHO, F.C. 1994. Disponibilidade e utilização de resíduos gerados no processamento agroindustrial do café. Inf. Econ., 24(1):9-16.

Recebido em: 27/06/00

Aceito em: 08/01/01 